\title{
INFLUENCE OF GLYPHOSATE CONCENTRATIONS ON SPRAY SOLUTION PHYSICOCHEMICAL CHARACTERISTICS AND DRIFT POTENTIAL
}

\author{
Dieimisson P. Almeida ${ }^{1 *}$, Marcelo da C. Ferreira ${ }^{2}$, Renata T. da S. Santos ${ }^{2}$, \\ Fabiano Griesang ${ }^{3}$, Eduardo de S. dos Santos ${ }^{2}$, Paulo C. Timossi ${ }^{4}$
}

${ }^{1 *}$ Corresponding author. COMIGO Institute of Science and Technology/ Rio Verde - GO, Brazil.
E-mail: dieimissonpa@gmail.com| ORCID ID: https://orcid.org/0000-0002-1549-8206

\section{KEYWORDS}

surface tension, contact angle, droplets, MVD, Congo grass.

\begin{abstract}
The herbicide glyphosate is sprayed with varying application volumes that result in different concentrations used in the spray solutions. Thus, this study aimed to evaluate the effect of glyphosate concentrations on the potential risk of droplet drift, surface tension of spray solution, and contact angle of droplets on surfaces. Three experiments were conducted in a completely randomized design. Drift potential was evaluated by median volumetric diameter (MVD), percentage volume of droplets with diameter smaller than $100 \mu \mathrm{m}(\% \mathrm{~V}<100 \mu \mathrm{m})$, and coefficient of uniformity (Span), with 12 replications. The surface tension of spray solutions and contact angle of droplets were evaluated on Urochloa ruziziensis leaves, paraffin film, and glass, with four replications. Changing glyphosate concentrations in the spray solution changes the droplet spectrum and contact angle on different surfaces due to changes in spray solution physicochemical characteristics, such as surface tension. The increased glyphosate concentrations in the spray solution lead to increased drift potential of droplets, reducing the surface tension and contact angle of droplets on surfaces.
\end{abstract}

\section{INTRODUCTION}

Glyphosate is a widely used herbicide worldwide, alone or in combination with other plant restricted translocation herbicides (Almeida et al., 2015). This herbicide inhibits the enzyme 5-enolpyruvylshikimate-3phosphate synthase (EPSPs), which is systemic rather than selective (Rodrigues \& Almeida, 2018).

Due to the optimization of herbicide spraying operation, the used application volumes have been getting lower, resulting in increasingly concentrated spray solutions. However, an increased concentration may interfere with the effectiveness (Almeida et al., 2014) and safety of applications due to the quality of spray solution distribution and deposition.

Spray solution physicochemical characteristics need to be considered to evaluate application efficiency, as they can interfere with the generated droplet spectrum and deposition, as well as the absorption and penetration of droplets by leaves. Among the main properties evaluated for herbicides are droplet size, surface tension, and contact angle, as they may influence the interaction of the spray solution with the target surface (Marques et al., 2012; Costa et al., 2017; Cunha et al., 2017).

Droplet size interferes with the wind drag and evaporation potential, with the effect of spray solution loss during the application process, which can result in spray solution distribution and target control irregularities, as well as environmental intoxication effects in the surroundings of application sites, which may vary in range and intensity depending on the combination of characteristics of the spray solution, spraying operation, and weather conditions (Glass et al., 2010; Griesang et al., 2017; Moraes et al., 2019; Preftakes et al., 2019).

Surface tension is the result of differences in intermolecular interactions of liquid-air interphase molecules with molecules within the liquid, i.e., surface tension is a reflection of cohesive forces in a liquid (Adamson \& Gast, 1997; Behring et al., 2004; Kronberg et al., 2014). In general, the lower the surface tension is, the higher the ability of a liquid to spread over a surface

\footnotetext{
${ }^{2}$ Paulista State University "Julio de Mesquita Filho"/ Jaboticabal - SP, Brazil.

${ }^{3}$ Jacto/ Pompéia - SP, Brazil.

${ }^{4}$ Federal University of Jataí/ Jataí - GO, Brazil.
} 
(Decaro Junior et al., 2015; Calore et al., 2015; Vechia et al., 2016). Spreading can be measured by the contact angle formed between a droplet and the surface where it has been deposited. However, the surface characteristics must be taken into account, as spreading is also a function of interfacial characteristics (liquid and surface component substances), as well as surface tension (Iost \& Raetano, 2010; Oliveira et al., 2019). Thus, spray solution spreading on plants depends on both surface tension of the liquid and anatomical constituents and biochemical composition of the epidermis (Kissmann, 1998; Behring et al., 2004; Barreto et al., 2017; He et al., 2019), which may also interfere with the differential penetration of products deposited on plants (Marques et al., 2012).

Thus, this study aimed to evaluate the effect of glyphosate concentrations in the spray solution on the drift potential of sprayed droplets, surface tension of spray solution, and contact angle of droplets on Urochloa ruziziensis leaves, paraffin film, and glass surfaces.

\section{MATERIAL AND METHODS}

The studies were carried out in the Nucleus of Study and Development in Application Technology (NEDTA) of the Department Fitossanidade - UNESP, Campus of Jaboticabal - SP, Brazil.

The effect of five acid equivalent (a.e.) concentrations of glyphosate was evaluated on spray solution characteristics and drift potential of sprayed droplets. For this, three experiments were carried out under laboratory conditions in a completely randomized design. The first and second experiments evaluated droplet size and surface tension of spray solutions of five glyphosate concentrations $\left(2.44,4.88,9.75,19.5,39 \mathrm{~g}\right.$ a.e. $\mathrm{L}^{-1}$ of spray solution) (Roundup Ultra ${ }^{\circledR}, 650 \mathrm{~g}$ a.e. $\mathrm{kg}^{-1}$, WG, Monsanto), with 12 and 4 replications, respectively. The third experiment evaluated the contact angle of droplets in a $5 \times 3$ factorial scheme (glyphosate concentrations in the spray solutions vs. surfaces), with four replications. The evaluations were carried out on two artificial surfaces (glass coverslips and paraffin film) and U. ruziziensis leaves.

The five acid equivalent concentrations of glyphosate $\left(2.44,4.88,9.75,19.5\right.$, and $39 \mathrm{~g} \mathrm{~L}^{-1}$ of spray solution) correspond to application volumes of 400, 200, $100,50,25 \mathrm{~L} \mathrm{ha}^{-1}$, respectively. A dose of $975 \mathrm{~g}$ a.e. ha ${ }^{-1}$ of glyphosate is sufficient to desiccate a cover plant such as U. ruziziensis (Silva et al., 2013; Timossi et al., 2016).

\section{Experiment 1: Evaluation of droplet size and drift potential}

Spray solution jet quality and of drift potential attributes (MVD, \%V $<100 \mu \mathrm{m}$, and Span), evaluated by droplet production by hydraulic energy spray nozzles in the treatments, are named in the text as droplet spectrum.

A MagnoJet AD-IA 110007 air-induction flat fan spray tip, commonly used by farmers to apply glyphosate at a working pressure of $300 \mathrm{kPa}$, providing a flow rate of $0.29 \mathrm{~L} \mathrm{~min}^{-1}$, was used in this experiment. Spraying was driven with compressed air, and the pressure was maintained constant at $320 \mathrm{kPa}$ in the spray tip by a precision pressure regulator to obtain a flow rate of 0.300 $\mathrm{L} \min ^{-1}$. The distance between the spray nozzle and the point of droplet interception by the laser was $0.4 \mathrm{~m}$ (FAO, 1998). The laser intercepted droplets produced across the full range of the jet $(50 \%)$, moving the nozzle transversely. The time taken to move from side to side of the applied jet was set to three seconds. Twelve replications were obtained with each glyphosate concentration in the spray solution (2.44, 4.88, 9.75, 19.5, and $39 \mathrm{~g}$ a.e. $\mathrm{L}^{-1}$ of spray solution), being four readings in three copies of the spray tip model.

Droplet diameter was determined by the laser diffraction method during the sprayed droplet passing through the sampling region of a particle size analyzer (Mastersizer S, Malvern Instruments Co.). In this method, the degree of diffraction that the light ray undergoes is inversely proportional to the particle size (Fernandes et al., 2007). Data decoding, according to the algorithm developed for droplet diameter characterization by laser diffraction, was processed and tabulated directly by the program integrated with the particle size analyzer (Mastersizer $\mathrm{S}^{\circledR}$, version 2.19).

The median volumetric diameter (MVD), coefficient of uniformity of sprayed droplets (Span), and percentage volume of droplets with diameter smaller than $100 \mu \mathrm{m}$ $(\% \mathrm{~V}<100 \mu \mathrm{m})$ were measured in the emitted spray solution.

Span was determined by [eq. (1)]:

$$
\text { Span }=\frac{\text { Dv0.9 }- \text { Dv0.1 }}{\text { Dv0.5 }}
$$

Where:

Dv0.1 is the droplet diameter such that $10 \%$ of the sprayed volume is composed by droplets of smaller diameter;

Dv0.5 is the droplet diameter such that $50 \%$ of the volume of the sprayed liquid consists of droplets larger or smaller diameter, and

Dv0.9 id the droplet diameter such that $90 \%$ of the sprayed volume is composed by droplets of smaller diameter (Matthews et al., 2016).

Spraying was driven by compressed air, and the pressure was maintained constant with a precision pressure regulator. The distance between the spray nozzle and the point of droplet interception by the laser was maintained at $0.4 \mathrm{~m}$. The laser intercepted droplets produced across the full range of the jet, moving the nozzle transversely. The time taken to move from side to side of the applied jet was set to three seconds.

\section{Experiments 2 and 3: Determination of surface tension of spray solutions and contact angle of droplets}

The surface tension of spray solutions at five acid equivalent concentrations (a.e.) of glyphosate $(2.44,4.87$, $9.75,19.5$, and $39 \mathrm{~g}$ a.e. $\mathrm{L}^{-1}$ of spray solution) was evaluated with four replications. The contact angle of droplets was evaluated in a $5 \times 3$ factorial scheme (glyphosate concentrations in the spray solution vs. surfaces), with four replications. The evaluations were carried out on two artificial surfaces (glass coverslips and paraffin film) and $U$. ruziziensis leaves.

Surface tension and contact angle were determined using an automatic tensiometer (Contact Angle System OCA 15-Plus, Dataphysics $\left.{ }^{\circledR}\right)$. The equipment was equipped with a digital camera with a 752 × 582-pixel and temporal resolution of 50 images $\mathrm{s}^{-1}$. Images were captured at a distance of $0.1 \mathrm{~m}$ and processed using the software $\mathrm{SCA} 20^{\circledR}$. The variables were determined with the 
droplets formed by a $500-\mu \mathrm{L}$ precision syringe $\left(\right.$ Hamilton $\left.^{\circledR}\right)$. Each droplet had a $5-\mu \mathrm{L}$ volume of spray solution.

Surface tension was determined by the pendant drop method, in which the image of the droplet formed at the tip of the needle is captured by the digital camera and analyzed by axis asymmetry. Surface tension is calculated based on the Yang-Laplace equation as a function of the deformation of droplets emitted in each sampling (Adamson \& Gast, 1997; Ferreira et al., 2013).

Three surfaces with different characteristics were used for the analysis of the contact angle of droplets: $U$. ruziziensis leaf, glass coverslip (one new coverslip per treatment), and paraffin film (a resistant mixture of plastic paraffin with waterproof paper - Parafilm $\left.\mathrm{M}^{\circledR}\right)$. After the droplet $(5 \mu \mathrm{L})$ is formed, it hung on the tip of the needle. Thus, for the droplet to settle on the surfaces, their bases hanging on the needle was touched to them. The syringe was rapidly withdrawn upwards using a hand-held conveyor after applying the droplet, followed by measurements. The contact angle has been used to characterize surfaces for affinity to aqueous spray solution droplets and their spreading over the surface. The surface is called hydrophilic (high spread) when this angle is lower than $90^{\circ}$, otherwise it is called hydrophobic (Tang et al., 2008).

Plants of the species $U$. ruziziensis were grown for four months at the full sun in pots filled with substrate composed of sand, soil, and cattle manure in a ratio of $3: 1: 1$, with daily irrigation until close to field capacity. During this period, three plant cuts were carried out at $0.05 \mathrm{~m}$ from the soil. After each cut, maintenance fertilization was performed according to technical recommendations for the crop (Sousa \& Lobato, 2004). Leaf harvesting was carried out after $U$. ruziziensis was grown for 45 days after the last cut.

Considering the genetic variability among $U$. ruziziensis genotypes, which may consequently change the morphology and anatomy of plant leaves (Santos et al. 2013), the penultimate leaves from the base to the upper part with visible ligule were harvested to determine the contact angle of spray solutions. They were sectioned into longitudinal rectangles of approximately $0.05 \times 0.01 \mathrm{~m}$. These sections were arranged horizontally in individual stretchers to reduce undulation that compromised leaf structure and image capture for contact angle readings. Images were evaluated every second for 60 seconds after each droplet was deposited individually on the leaf surface. The analysis of surface tension and contact angle considered four evaluation times $(5,15,30$, and 60 seconds) after droplet formation (surface tension) or deposition (contact angle). The mean temperature and relative humidity during the readings were $26.9 \pm 2{ }^{\circ} \mathrm{C}$ and $47 \pm 2 \%$, respectively.

\section{Data analysis}

The results obtained in the evaluations were submitted to analysis of variance by the software Assistat 7.7 to detect the significance of glyphosate concentrations in the spray solution for the variables of the droplet spectrum, surface tension, contact angle, and the interaction between factors (surfaces vs. concentrations).

In the event of a significant interaction of the contact angle results between the studied factors, the concentrations were sliced within each surface by nonlinear regression. Models were selected considering the significance of the analysis of variance of the regression, coefficient of determination $\left(\mathrm{R}^{2}\right)$, and the significance of their parameters using the Student's t-test.

The values of the droplet spectrum (MVD, $\% \mathrm{~V}<100 \mu \mathrm{m}$, and Span) and surface tension of spray solutions were adjusted to a quadratic model (Equation 2), using the software Sigma Plot 12.3:

$$
y=c+a \cdot x+b \cdot x^{2}
$$

Where:

$\mathrm{y}$ is the dependent variable;

$\mathrm{x}$ is the independent variable, and

$\mathrm{a}, \mathrm{b}$, and c are estimated model parameters.

The values of contact angle as a function of glyphosate concentrations in the spray solution on the adaxial surface of $U$. ruziziensis, paraffin film, and glass coverslips were fit to hyperbolic (Equation 3), quadratic with inverse function (Equation 4), and exponential models (Equation 5), respectively, using the software Sigma Plot 12.3.

$$
\begin{aligned}
& y=\frac{a \cdot b}{(b+x)} \\
& y=\left(\frac{a}{x}\right)+\left(\frac{b}{x^{2}}\right)+c \\
& y=a \cdot \exp ^{(-b \cdot x)}+c
\end{aligned}
$$

Pearson's linear correlation was calculated between MVD, $\% \mathrm{~V}<100 \mu \mathrm{m}$, and Span, surface tension of spray solutions and MVD, and surface tension of spray solutions and contact angle of droplets, separately for each surface at 60 seconds. The significance of correlations was calculated by the Student's t-test.

\section{RESULTS AND DISCUSSION}

The evaluations of the effect of glyphosate concentrations on spray solution characteristics and drift potential of the sprayed droplets showed differences in the droplet spectrum (Table 1). By increasing glyphosate concentrations in the spray solution (Figures $1 \mathrm{~A}$ to $1 \mathrm{C}$ ), MVD, $\% \mathrm{~V}<100 \mu \mathrm{m}$, and Span responded quadratically with significance $\leq 0.06$.

TABLE 1. F-values and coefficients of variation (CV\%) applied to the means of median volumetric diameter (MVD), percentage volume of droplets smaller than $100 \mu \mathrm{m}(\% \mathrm{~V}<100 \mu \mathrm{m})$, and coefficient of uniformity (Span).

\begin{tabular}{cccc}
\hline Variable & \multicolumn{3}{c}{ Droplet spectrum } \\
\cline { 2 - 4 } & $\operatorname{MVD}(\mu \mathrm{m})$ & $\% \mathrm{~V}<100 \mu \mathrm{m}$ & $\mathrm{Span}$ \\
\hline F for droplet spectrum & $118.8497^{* *}$ & $76.6068^{* *}$ & $21.3106^{* *}$ \\
\hline CV $(\%)$ & 6.06 & 12.67 & 11.47 \\
\hline
\end{tabular}


** Significant at $1 \%$ significance.

Increasing herbicide concentrations from 2.44 to $19.5 \mathrm{~g}$ a.e. $\mathrm{L}^{-1}$ reduced MVD from 548 to $369 \mu$ m, respectively, while a spray solution at a concentration of $39 \mathrm{~g}$ a.e. $\mathrm{L}^{-1}$ resulted in an MVD of $372 \mu \mathrm{m}$. The response of $\% \mathrm{~V}<100 \mu \mathrm{m}$ and Span to glyphosate concentrations in the spray solution was inverse to MVD.

A)

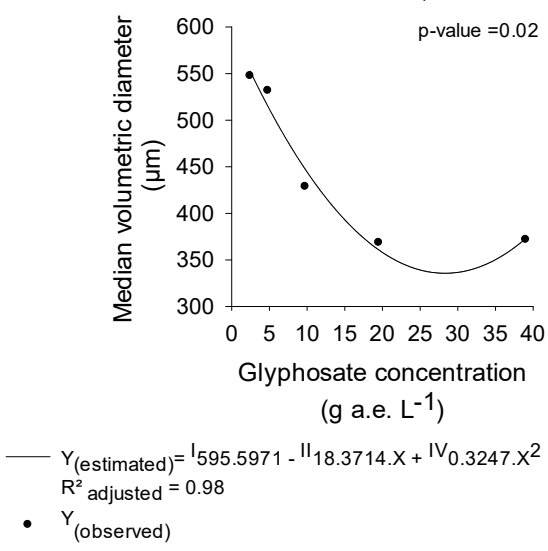

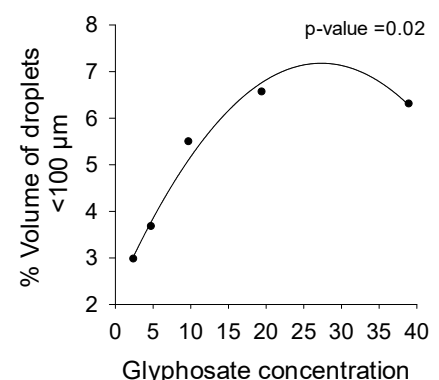
(g a.e. $\mathrm{L}^{-1}$ )

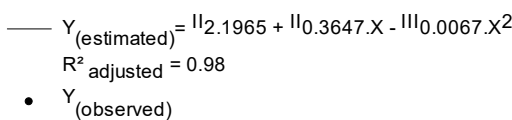

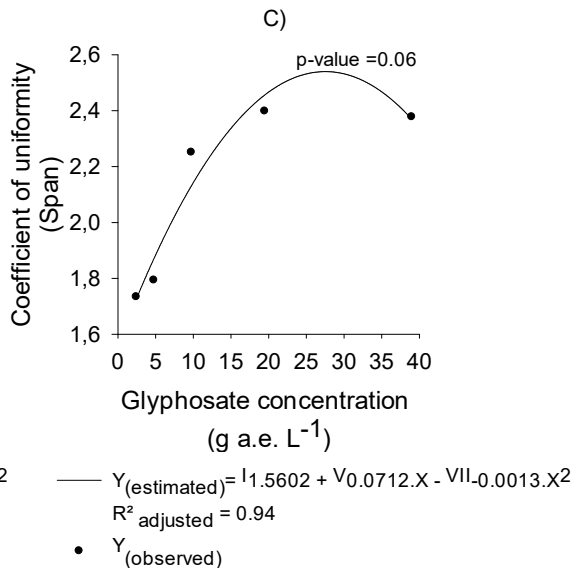

- ${ }_{\text {(observed) }}$

I, II, III, V e VII Significant at 1, 2, 3, 5, and 7\% of significance, respectively, by the t-test.

FIGURE 1. (A) Median volumetric diameter of droplets, (B) percentage volume of droplets smaller than $100 \mu \mathrm{m}$, and (C) coefficient of uniformity (Span) provided by concentrations of $2.44,4.88,9.75,19.5,39 \mathrm{~g} \mathrm{~L}^{-1}$ of acid equivalent (a.e.) of glyphosate with the spray tip ADIA 110007.

Considering the droplet size classification established by the standard S572.1 (ASABE, 2009), prepared by droplet spectrum analysis generated by reference spray tips, glyphosate concentrations in the spray solution provided MVD classified as extremely thick (2.44 and $4.88 \mathrm{~g}$ a.e. $\mathrm{L}^{-1}$ of spray solution), very thick (9.75 g a.e. $\mathrm{L}^{-1}$ of spray solution), and thick (19.5 and $39 \mathrm{~g}$ a.e. $\mathrm{L}^{-1}$ of spray solution).

Herbicide concentration in the spray solution acts with different intensities on MVD for different spray tip models. Almeida et al. (2016) observed that the increased concentration of the herbicide diquat from 2 to $4 \mathrm{~g}$ a.i. $\mathrm{L}^{-1}$ of spray solution resulted in a reduction in the size of droplets generated by air-induction tips from 599 to 590 $\mu \mathrm{m}$, respectively, while tips that generate droplets without air induction increased MVD from 166 to $190 \mu \mathrm{m}$.

$\mathrm{Yu}$ et al. (2009a; 2009b) found that deposit formation by droplets on waxy and hairy leaf surfaces is influenced by droplet size associated with spray solution characteristics. In this sense, $\mathrm{Xu}$ et al. (2010) found that $300-\mu \mathrm{m}$ droplets had a spreading time (2.6 s) 9.7 times faster than $600-\mu \mathrm{m}$ droplets $(25.3 \mathrm{~s})$ for the wet area in the interveinal surface area of the adaxial surface of Syringa reticulata leaves.
From the biological point of view, changes in droplet size associated with glyphosate concentrations in the spray solution may influence the relationship between glyphosate absorption and translocation differently in different plant species and, consequently, their control effectiveness and/or intoxication (Prasad \& Cadogan 1992; Liu et al., 1996; Feng et al., 2003).

Pearson's correlation coefficient was negative between MVD and $\% \mathrm{~V}<100 \mu \mathrm{m}$ and Span in the order of -0.99 , with significance levels lower than $1 \%$ by the ttest. Thus, there is a proportional increase in $\% \mathrm{~V}<100 \mu \mathrm{m}$ and Span as MVD is reduced, leading to a higher drift potential.

Glyphosate concentrations in the spray solution influenced the surface tension at all evaluated times (Table 2 ), possibly due to the proportional increase in the concentration of surfactants in the inert of the commercial product formulation containing glyphosate used in this research (Oliveira et al., 2015). Thus, surface tension values as a function of concentrations fit a quadratic model (Figures 2A to 2D), with significances of the F-test of regression of $0.05,0.11,0.11$, and 0.09 at $5,15,30$, and 60 seconds, respectively.

TABLE 2. F-values and coefficients of variation (CV\%) applied to the means of surface tension ( $\left.\mathrm{mN} \mathrm{m}^{-1}\right)$ of the spray solutions.

\begin{tabular}{ccccc}
\hline Variable & \multicolumn{3}{c}{ Time after droplet formation } \\
\cline { 2 - 5 } & $5 \mathrm{~s}$ & $15 \mathrm{~s}$ & $30 \mathrm{~s}$ & $60 \mathrm{~s}$ \\
\hline $\mathrm{F}_{\text {calculated }}$ for surface tension & $19.6916^{* *}$ & $25.2160^{* *}$ & $37.5053^{* *}$ & $28.1776^{* *}$ \\
\hline $\mathrm{CV}(\%)$ & 1.21 & 0.95 & 0.71 & 0.79 \\
\hline
\end{tabular}

**Significant at $1 \%$ probability level.

The quadratic fit of the surface tension (Figures 2A to 2D) was similar to MVD (Figure 1A). Thus, at 5, 15, 30, and 60 seconds, spray solutions with 2.44 to $19.5 \mathrm{~g}$ a.e. $\mathrm{L}^{-1}$ provided a reduction in surface tension, while the concentrated spray solution $\left(39 \mathrm{~g}\right.$ a.e. $\left.\mathrm{L}^{-1}\right)$ showed an increase compared to $19.5 \mathrm{~g}$ a.e. $\mathrm{L}^{-1}$. 
A)

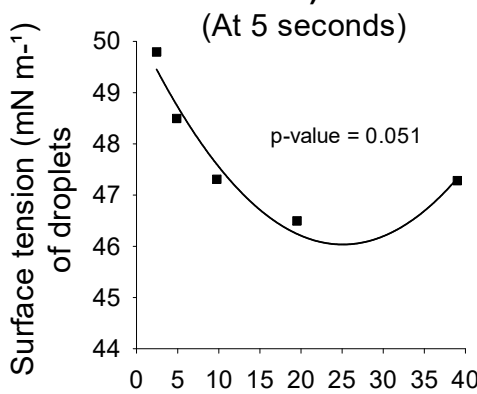

B)

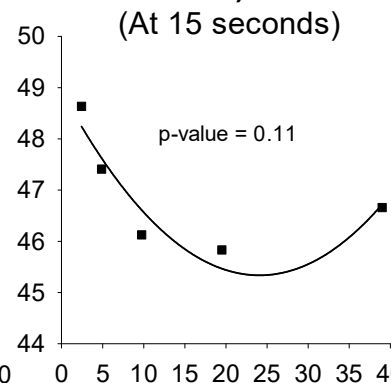

C)

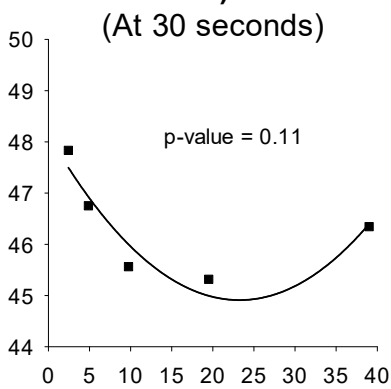

D)

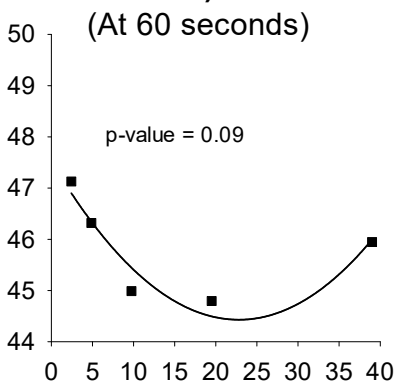

Glyphosate concentration(g a.e. L-1)

- $Y$ (observed)

Adjusted quadratic models

$$
\begin{aligned}
& -Y_{(\text {estimated })}={ }^{I} 50.2304-I^{I I} 0.3345 . X+I V_{0.0067 . X} X^{2} \\
& \mathrm{R}^{2} \text { adjusted }=0.90 \\
& \begin{array}{r}
-Y \text { (estimated })={ }^{I} 50,2304-\mathrm{VI}_{0,3345 . X+{ }{ }^{\mathrm{VIII}} 0,0062 . \mathrm{X}^{2}} \\
\mathrm{R}^{2} \text { adjusted }=0.77
\end{array}
\end{aligned}
$$

$$
\begin{gathered}
\text { (At } 30 \text { seconds) } \\
-Y_{\text {(estimated) }}={ }^{\mathrm{I}} 48.1389-{ }^{\mathrm{VI}_{0.2778 . X}+{ }^{\mathrm{VII}} 0.0061 . \mathrm{X}^{2}} \\
\mathrm{R}^{2} \text { adjusted }=0.79 \\
\text { (At } 60 \text { seconds) } \\
\mathrm{Y}_{\text {(estimated) }}={ }^{\mathrm{I}} 47.5284-\mathrm{V}_{0.2717 . \mathrm{X}+\mathrm{V}_{0.006 . \mathrm{X}^{2}}} \\
\mathrm{R}^{2} \text { adjusted }=0.81
\end{gathered}
$$

I, II, III, IV, V, VI, VII e VIII Significant at 1, 2, 3, 4, 5, 6, 7, and 8\% of probability, respectively, by the t-test.

FIGURE 2. Surface tension $\left(\mathrm{mN} \mathrm{m}^{-1}\right)$ as a function of concentrations of $2.44,4.78,9.75,19.5$, and $39 \mathrm{~g} \mathrm{~L}^{-1}$ of acid equivalent (a.e.) of glyphosate in the spray solution. (A) At 5 seconds; (B) at 15 seconds; (C) at 30 seconds; (D) at 60 seconds.

The positive correlation between surface tension and MVD was 0.79 , with a significance level lower than $5 \%$ by the t-test. It indicates that MVD decreases (Figure 1A) as glyphosate concentrations reduce spray solution surface tension (Figures 2A to 2D). On the contrary, higher surface tension results in increased droplet size. A better droplet uniformity is also observed, with a reduction in the values of $\% \mathrm{~V}<100 \mu \mathrm{m}$ (Figures 1B to 1C).

The results of this research corroborate those of Oliveira et al. (2015), who found an inversely proportional correlation between surface tension and MVD using different concentrations of associated phytosanitary products. Therefore, reducing the volume of application and maintaining the dose of phytosanitary products will increase the concentration in the spray solution, which results in the alteration of its physicochemical characteristics, such as surface tension and droplet spectrum, leading to a higher drift potential (Griesang et al., 2017).

The contact angle showed a significant interaction ( $>0.01)$ between glyphosate concentrations and surfaces (U. ruziziensis leaves, paraffin film, and glass) at the four analyzed times (Table 3). The interactions indicate that contact angle is dependent on target surface characteristics, such as polarity and physicochemical characteristics of spray solutions, such as surface tension (Kissmann, 1998; Behring et al., 2004; He et al., 2019; Iost \& Raetano, 2010; Decaro Junior et al., 2015; Barreto et al., 2017; Oliveira et al., 2019).

TABLE 3. F-values, factor means, and coefficients of variation (CV\%) applied to the means of contact angle on the surface of U. ruziziensis leaves, paraffin film, and glass.

\begin{tabular}{lcccc}
\hline \multirow{2}{*}{ Variable } & \multicolumn{4}{c}{ Time after droplet formation } \\
\cline { 2 - 5 } & $5 \mathrm{~s}$ & $15 \mathrm{~s}$ & $30 \mathrm{~s}$ & $60 \mathrm{~s}$ \\
\hline $\mathrm{F}_{\text {calculated }}$ for surface $(\mathrm{S})$ & $1237.8773^{* *}$ & $1644.1039^{* *}$ & $1346.3358^{* *}$ & $1314.1447^{* *}$ \\
$\mathrm{~F}_{\text {calculated }}$ for concentration $(\mathrm{C})$ & $103.6003^{* *}$ & $132.7576^{* *}$ & $104.3338^{* *}$ & $89.0063^{* *}$ \\
$\mathrm{~F}_{\text {calculated }}$ for $\mathrm{S} \times \mathrm{C}$ & $20.1507^{* *}$ & $29.4343^{* *}$ & $27.5734^{* *}$ & $27.4780^{* *}$ \\
\hline $\mathrm{CV}(\%)$ & 7.22 & 6.55 & 7.48 & 7.84 \\
\hline
\end{tabular}

**Significant at $1 \%$ probability level.

The values of contact angle as a function of glyphosate concentrations in the spray solution on the adaxial surface of the $U$. ruziziensis leaf, paraffin film, and glass coverslips were adjusted to hyperbolic, quadratic inverse, and exponential models, respectively. The significance of the F-test of regressions was lower than 0.04 , with coefficients of determination higher than 0.81 (Table 4 and Figure 3). 
TABLE 4. Parameters and coefficient of determination of models adjusted to the values of contact angle as a function of glyphosate concentrations in the spray solution on the adaxial surface of $U$. ruziziensis leaves, paraffin film, and glass coverslips.

\begin{tabular}{|c|c|c|c|c|c|c|}
\hline \multirow{2}{*}{$\underset{\mathscr{E}}{\stackrel{\mathscr{C}}{\Xi}}$} & \multirow{2}{*}{ Time (s) } & \multirow{2}{*}{ Adjusted model } & \multicolumn{3}{|c|}{ Parameter } & \multirow{2}{*}{$\begin{array}{c}\begin{array}{c}\text { Coefficients of } \\
\text { determination }\end{array} \\
\mathrm{R}^{2} \text { (adjusted) }\end{array}$} \\
\hline & & & $\dagger a$ & $\dagger b$ & ${ }^{\dagger} c$ & \\
\hline \multirow{4}{*}{ 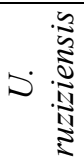 } & 5 & Hyperbolic & ${ }^{\mathrm{I}} 120.3422$ & $\mathrm{VI}_{45.9328}$ & & 0.81 \\
\hline & 15 & Hyperbolic & I1 121.6473 & $\mathrm{VI}_{40} 0.4663$ & & 0.82 \\
\hline & 30 & Hyperbolic & I 120.0308 & $v_{35.5429}$ & & 0.85 \\
\hline & 60 & Hyperbolic & I119.9706 & $v_{34.1261}$ & & 0.85 \\
\hline \multirow{4}{*}{ 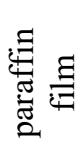 } & 5 & Inverse quadratic & XXIV 11.0609 & $\mathrm{IX}_{435550}$ & I75.5144 & 0.99 \\
\hline & 15 & Inverse quadratic & XXXII9.9827 & XVI37.1265 & I73.7168 & 0.99 \\
\hline & 30 & Inverse quadratic & IV 16.1813 & $\mathrm{xv}_{15.5122}$ & I72.2157 & 0.99 \\
\hline & 60 & Inverse quadratic & I 18.6952 & XXII_8.3196 & ${ }^{\mathrm{I}} 71.4682$ & 0.99 \\
\hline \multirow{4}{*}{$\frac{\tilde{D}}{\tilde{E}}$} & 5 & Exponential & ${ }^{\mathrm{II}} 64.7339$ & VIII_-0.1621 & XXVI5.6761 & 0.95 \\
\hline & 15 & Exponential & II 65.9952 & VI-0.1940 & $\mathrm{x}_{5.4116}$ & 0.96 \\
\hline & 30 & Exponential & ${ }^{\mathrm{VI}} 66.7183$ & III_-0.2295 & XXIX 5.1496 & 0.92 \\
\hline & 60 & Exponential & ${ }^{\mathrm{VI}} 58.6852$ & XII_-0.2303 & XXVII 4.8171 & 0.92 \\
\hline
\end{tabular}

${ }^{\dagger}$ Roman numerals represent the p-value of the significance of parameters by the t-test.

The behavior of deposited droplets, represented by the contact angle, resulted from the interaction between surface and concentrations (Figure 4). Glyphosate concentrations in the spray solutions promoted a reduction in the contact angle on the adaxial surface of $U$. ruziziensis leaf in the four evaluated times. On the other hand, artificial surfaces (paraffin film and glass coverslip) showed a stabilization in the reduction of contact angle at all analyzed times from the glyphosate concentration of $9.75 \mathrm{~g}$ a.e. $\mathrm{L}^{-1}$ of spray solution (Figure 4 ).
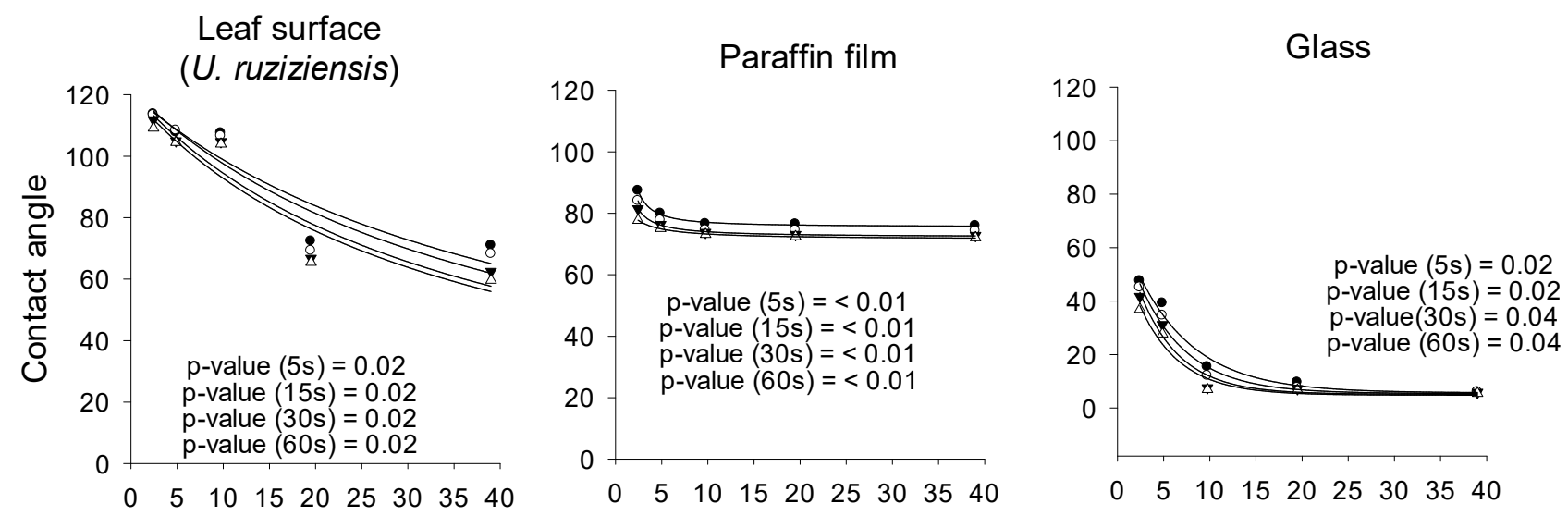

Glyphosate concentration (g a.e. L-1)

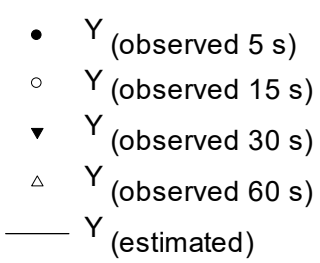

FIGURE 3. Contact angle on three surfaces as a function of concentrations of $2.44,4.78,9.75,19.5$, and $39 \mathrm{~g} \mathrm{~L}^{-1}$ of acid equivalent (a.e.) of glyphosate in the spray solution.

Contact angles of droplets on the adaxial surface of $U$. ruziziensis leaf were high compared to those obtained on glass coverslips for all concentrations and evaluated times (Figure 3). It is due to leaf characteristics, such as high wax content in the epicuticular layer and pilosity (Figure 4). The contact angle of droplets on the adaxial surface of $U$. ruziziensis leaf was high compared to the paraffin film only at concentrations of $2.44,4.88$, and 9.75 g a.e. $\mathrm{L}^{-1}$ (Figures 3 and 4 ). In other words, the increase in glyphosate concentration resulted in higher spreading on the leaf, which is explained by the high correlation with surface tension. This droplet behavior in the glass coverslip, which resulted in the lowest values than the other surfaces (Figures 3 and 4), is due to the possible hydrophilic characteristic of the glass. This behavior was not observed on paraffin film due to its hydrophobic characteristics. 


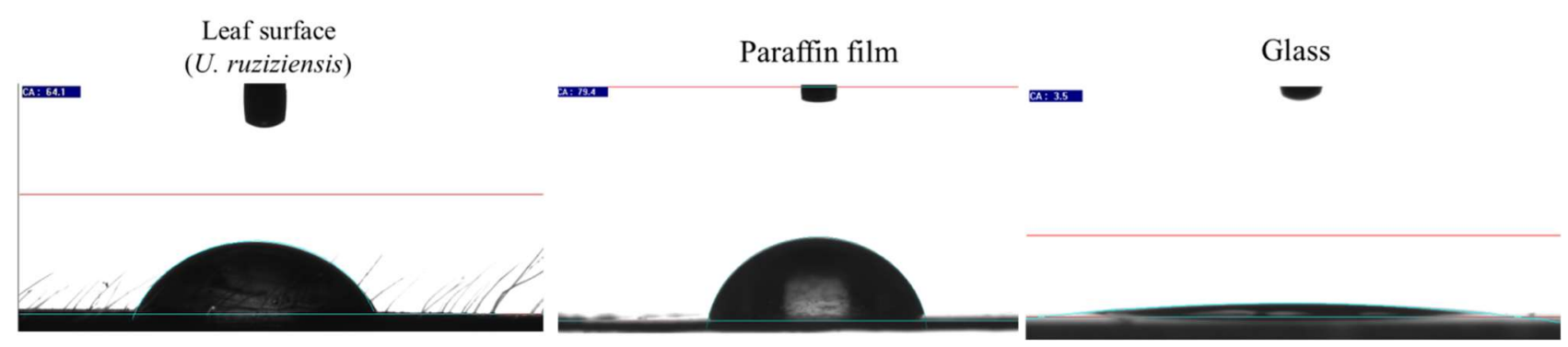

FIGURE 4. Contact angle on three surfaces as a function of the concentration of $39 \mathrm{~g} \mathrm{~L}^{-1}$ acid equivalent (a.e.) of glyphosate in the spray solution at 60 seconds

Droplets of spray solutions sprayed on hydrophilic surfaces provide their higher spreading, with lower contact angle and, consequently, higher interfacial contact, which may result in a higher spray solution absorption and evaporation rate than hydrophobic surfaces. Both the rate of absorption and evaporation are naturally dependent on the specific characteristics of the leaf surface, liquid, and weather conditions (Iost \& Raetano, 2010; Decaro Junior et al., 2015; Barreto et al., 2017; Oliveira et al., 2019; He et al., 2019). Because of the high contact angle, $U$. ruziziensis leaf surface may have small areas wetted by droplets (Decaro Junior et al., 2015), thus reducing the evaporation rate under the weather at application time and after it (Yu et al., 2009a; Yu et al., 2009b; Xu et al., 2010; $\mathrm{Xu}$ et al., 2011). Therefore, it may allow longer leaf wetness by droplets to affect the penetration of phytosanitary products directly in the epicuticular layer and their absorption and translocation (Liu et al., 1996).

A positive correlation was observed between the contact angle of droplets and surface tension of spray solution in the order of $0.46,0.83$, and 0.87 for $U$. ruziziensis leaves, paraffin film, and glass, respectively. Their respective levels of significance were 23,4 , and $2 \%$ by the t-test. It shows that the contact angle for the leaf surface of $U$. ruziziensis has limitations when estimated indirectly through values of spray solution surface tension. Thus, measuring the contact angle directly with appropriate image analysis criteria is important to avoid variable results due to the presence of pilosity, which may confuse the interpretation of the formed angle in the digitally captured image with computerized and automated analysis.

Based on the results of this research, changing glyphosate concentrations in the spray solution leads to changes in the droplet spectrum due to alterations in the physicochemical characteristics of the spray solution, such as surface tension. The contact angle has a different pattern between surfaces and is responsive to glyphosate concentration in the spray solution. Therefore, because the contact angle of droplets is positively correlated with spreading, they may influence target coverage, spray solution retention (Decaro Junior et al., 2015), evaporation, absorption, and translocation. In this sense, special attention is required in night applications, even at low application volumes, as the presence of free water on the leaf surface of $U$. ruziziensis from dew or wetting caused by positive root pressure, or even due to precipitation events, as there may be dilution of the spray solution on the leaf surface, which may lead to dripping, compromising control effectiveness of applications.

\section{CONCLUSIONS}

Increasing glyphosate concentrations in the spray solution influence droplet spectrum (MVD and $\% \mathrm{~V}<100$ $\mu \mathrm{m})$, surface tension, and contact angle of droplets with the surfaces $U$. ruziziensis leaf, paraffin film, and glass. Increasing glyphosate concentrations increase the potential risk of droplet drift and reduce the contact angle of droplets interacting with the surfaces $U$. ruziziensis leaf, glass coverslips, and paraffin film.

\section{REFERENCES}

Adamson AW, Gast AP (1997) Capillarity. In: Physical Chemistry of Surfaces. New York, WileyInterscience, 6 ed. p4-43.

Almeida DP, Timossi PC, Lima SF, Silva UR, Reis EF (2014) Condições atmosféricas e volumes de aplicação na dessecação de Urochloa ruziziensis e vegetação espontânea. Revista Brasileira de Herbicidas 13(3):245251. DOI: http://dx.doi.org/10.7824/rbh.v13i3.281

Almeida DP, Timossi PC, Lima SF, Silva UR. Reis EF (2015) Droplets size categories and application volumes in burndown of plant covers. Revista Brasileira de Herbicidas 14(1):73-82. DOI: http://dx.doi.org/10.7824/rbh.v14i1.280

Almeida DP, Agostini, AR, Yamauchi AK, Decaro Júnior ST, Ferreira MC (2016) Application volumes and sizes of droplets for the application of diquat herbicide in the control of Eichhornia crassipes. Planta Daninha 34(1):171-179. DOI: http://dx.doi.org/10.1590/S010083582016340100018

ASABE - American Society of Agricultural and Biological Engineers (2009) Spray nozzle classification by droplet spectra. ASABE, 4 p. (ANSI/ASAE S572.1)

Barreto LF, Decaro RA, Silva MG, Griesang F; Ferreira MC (2017) Efeito do paraquat e glyphosate sobre espécimes de poaceae e convolvulaceae em condições de déficit hídrico. Revista Brasileira de Herbicidas 16(3):198205. DOI: https://doi.org/10.7824/rbh.v16i3.554

Behring JL, Lucas M, Machado C, Barcellos IO (2004) Adaptação no método do peso da gota para determinação da tensão superficial: Um método simplificado para a quantificação da CMC de surfactantes no ensino da química. Química Nova 27(3):492-495. DOI: http://dx.doi.org/10.1590/S0100-40422004000300021 
Calore RA, ferreira MC, Galli JC (2015) Efeitos de adjuvantes no controle de Enneothrips flavens Moulton, 1941 (Thysanoptera: trypidae) na cultura do amendoim. Agrária 10(1):74-81. DOI:

http://dx.doi.org/10.5039/agraria.v10i1a5043

Costa LL, Silva HJPS, Almeida DP, Ferreira MC, Pontes NC (2017) Droplet spectra and surface tension of spray solutions by biological insecticide and adjuvants.

Engenharia Agrícola 37(2):292-301, DOI:

http://dx.doi.org/10.1590/1809-4430-

eng.agric.v37n2p292-301/2017

Cunha JPAR, Alves GS, Marques RS (2017) Tensão superficial, potencial hidrogeniônico e condutividade elétrica de caldas de produtos fitossanitários e adjuvantes. Revista Ciência Agronômica 48(2):261-270. DOI: http://dx.doi.org/10.5935/1806-6690.20170030

Decaro Junior ST, Ferreira MC, Lasmar O (2015) Physical characteristics of oily spraying liquids and droplets formed on coffee leaves and glass surfaces. Engenharia Agrícola 35(3):588-600. DOI: http://dx.doi.org/10.1590/1809-4430Eng.Agric.v35n3p588-600/2015

FAO - Food and Agriculture Organization of the United Nations (1998) Agricultural pesticide sprayers. FAO, p62.

Feng PCC, Chiu TR, Sammons D, Ryerse JS (2003) Droplet size affects glyphosate retention, absorption, and translocation in corn. Weed Science 51(3):443-448. DOI: https://doi.org/10.1614/0043-

1745(2003)051[0443:DSAGRA]2.0.CO;2

Ferreira MC, Lasmar O, Decaro Junior ST, Neves SS, Azevedo LH (2013) Qualidade da aplicação de inseticida em amendoim (Arachis hypogaea L1.), com e sem adjuvantes na calda, sob chuva simulada. Biosciense Journal 29(Supplement 1):1431-1440.

Fernandes AP, Parreira RS, Ferreira MC, Romani GN (2007) Caracterização do perfil de deposição e do diâmetro de gotas e otimização do espaçamento entre bicos na barra de pulverização. Engenharia Agrícola 27(3):728-733. DOI: http://dx.doi.org/10.1590/S0100-69162007000400016

Glass R, Mathers J, Harrington P, Miller PCH, Lane A, O'Sullivan CM, Ferreira MC (2010) Comparative field drift data from applications to tall and short crops with modern operating conditions. In: International Advances in Pesticide Application,Cambridge, UK. Aspects of Applied Biology (99):409-412.

Griesang F, Decaro RA, Santos CAM, Santos ES, Roque NHL, Ferreira MC (2017) How much do adjuvant and nozzles models reduce the spraying drift? Drift in agricultural spraying. American Journal of Plant Sciences 8(11):2785-2794. DOI:

https://doi.org/10.4236/ajps.2017.811188

He Y, Xiao S, Wu J, Fang H (2019) Influence of multiple factors on the wettability and surface free energy of leaf surface. Applied Scinces 9(3):593. DOI:

https://doi.org/10.3390/app9030593

Iost CAR, Raetano CG (2010) Tensão superficial dinâmica e ângulo de contato de soluções aquosas com surfatantes em superfícies artificiais e naturais. Engenharia Agrícola 30(4):670-680.
Kissmann KG (1998) Adjuvantes para caldas de produtos fitossanitários. Em: Guedes JVC, Dornelles SB.

Tecnologia e segurança na aplicação de agrotóxicos: novas tecnologias. Santa Maria, Departamento de Defesa Fitossanitária, Sociedade de Agronomia de Santa Maria, p39-51.

Kronberg B, Holmberg K, Lindman B (2014) Surface and Interfacial Tension. In: Kronberg B, Holmberg K, Lindman B. Surface chemistry of surfactants and polymers. Wiley, United Kingdom, p231-249.

Liu SH, Campbell RA, Studens JA, Source RGW (1996) Absorption and translocation of glyphosate in aspen (Populus tremuloides Michx.) as influenced by droplet size, droplet number, and herbicide concentration. Weed Science 44(3):482-488.

Marques RP, Rodella RA, Martins D (2012)

Características da anatomia foliar de espécies de braquiária e sua relação com a sensibilidade a herbicidas. Planta Daninha 30(4):809-816. DOI:

http://dx.doi.org/10.1590/S0100-83582012000400015

Matthews GA, Bateman R, Miller P (2016) Gotículas de Pulverização. In: Matthews GA, Bateman R, Miller P. Métodos de aplicação de defensivos agrícolas. São Paulo, Andrei, 4 ed. p129-170.

Moraes ED, Saab OJGA, Gandolfo MA, Marubayashi, RYP, Gandolfo UD (2019) Potential risk of drift from inclined fan nozzles. Revista Brasileira de Engenharia Agrícola e Ambiental 23(3):229-233. DOI:

https://dx.doi.org/10.1590/1807-

1929/agriambi.v23n3p229-233

Oliveira RB, Antuniassi UR, Gandolfo MA (2015) Spray adjuvant characteristics affecting agricultural spraying drift. Engenharia Agrícola 35(1):109-116. DOI: 10.1590/1809-4430-Eng.Agríc.v35n1p109-116/2015

Oliveira RB, Precipito LMB, Gandolfo MA, Oliveira JV, Lucio FR (2019) Effect of droplet size and leaf surface on retention of 2,4-D formulations. Crop Protection 119(1):97-101. DOI:

https://doi.org/10.1016/j.cropro.2019.01.015

Preftakes CJ, Schleier JJ, Kruger GR, Weaver DK, Peterson RKD (2019) Effect of insecticide formulation and adjuvant combination on agricultural spray drift.

PeerJournal 19(7):e7136. DOI:

https://doi.org/10.7717/peerj.7136

Prasad R, Cadogan BL (1992) Influence of droplet size and density on phytotoxicity of three herbicides. Weed Technology 6(2):415-423.

Rodrigues BN, Almeida FS (2018) Guia de herbicidas. Londrina, 7 ed. 764p.

Santos FC, Techio VH, Freitas AS, Castro EM, Davide, LC, Sobrinho FS (2013) Adaptive leaf anatomical characteristics of Brachiaria ruziziensis genotypes (Poaceae) in different environments. Acta Scientiarum. Biological Sciences 35(4):579-584. DOI:

https://10.4025/actascibiolsci.v35i4.18265 
Silva UA, Timossi PC, Almeida DP, Lima SF (2013)

Eficácia do glyphosate na dessecação de espécies de

Urochloa. Revista Brasileira de Herbicidas 12(2):202-209.

DOI: https://doi.org/10.7824/rbh.v12i2.221

Sousa DMG, Lobato E (2004) Cerrado: correção do solo e adubação. Planaltina, Embrapa Cerrados, 2 ed. 416p.

Tang X, Dong J, Li X (2008) A comparison of spreading behaviors of Silwet L-77 on dry and wet lotus leaves. Journal of Colloid and Interface Science 325(1):223-227. DOI: https://doi.org/10.1016/j.jcis.2008.05.055

Timossi PC, Almeida DP, Ramos AR, Felisberto PAC, Lima SF, Silva UR (2016) Glyphosate effectiveness in the burndown of signalgrass at two levels of biomass. Revista Brasileira de Herbicidas 15(4):313-322. DOI: http://dx.doi.org/10.7824/rbh.v15i4.490

Vechia JFD, Santos RTS, Andrade DJ, Ferreira MC (2016) Physical characteristics of insecticide spraying liquids with mineral oil and droplets formed on citrus leaves. Citrus Research \& Technology 37(1):102-107. DOI: http://dx.doi.org/10.4322/crt.ICC083
Xu L, Zhu H, Ozkan HE, Thistle HW (2010) Evaporation rate and development of wetted area of water droplets with and without surfactant at different locations on waxy leaf surfaces. Biosystems Engineering 106(1):58-67. DOI: https://doi.org/10.1016/j.biosystemseng.2010.02.004

Xu L, Zhu H, Ozkan HE, Bagley WE, Krause CR (2011) Droplet evaporation and spread on waxy and hairy leaves associated with the type and concentration of adjuvants. Pest Management Science 67(7):842-851. DOI: https://doi.org/10.1002/ps.2122

Yu Y, Zhu H, Ozkan HE (2009a) Evaporation of pesticide droplets on surface under various relative humidity conditions. Journal of ASTM International 6(1):1-8. DOI: https://doi.org/10.1520/JAI101491

Yu Y, Zhu H, Ozkan HE, Derksen RC, Krause CR (2009b) Evaporation and deposition coverage área of droplets containing insecticides and spray additives on hydrophilic, hydrophobic, and crabapple leaf surfaces. Transactions of ASABE 52(1):39-49. DOI: https://doi.org/10.13031/ 2013.25939 